p-ISSN : 2541-6782, e-ISSN : 2580-6467

\title{
PEMANFAATAN TEKNOLOGI INFORMASI DAN KOMUNIKASI SEBAGAI MEDIA PEMBELAJARAN MATA PEMBELAJARAN PRAKARYA DI MTS NEGERI 5 DEMAK
}

\author{
Entin Dwi Herlina \\ MTs Negeri 5 Demak Jawa Tengah \\ E-mail: entin.herlina@yahoo.com
}

\begin{abstract}
Abstrak
Penelitian bertujuan untuk mengetahui Bagaimana Pemanfaatan Teknologi Informasi dan Komunikasi sebagai media pembelajaran pada mata pelajaran prakarya di MTs Negeri 5 Demak. Untuk mengetahui kendala-kendala yang dihadapi MTs Negeri 5 Demak dalam pemanfaatan Teknologi Informasi dan Komunikasi sebagai media pembelajaran, dan untuk mengetahui upaya apa yang dilakukan untuk mengatasi kendala-kendala yang dihadapi dalam pemanfaatan Teknologi Informasi dan Komunikasi sebagai media pembelajaran mata pelajaran prakarya di MTs Negeri 5 Demak. Hasil penelitian menunjukkan: (1) Pemanfaatan TIK sebagai media pembelajaran cukup maksimal, (2). Kendala pemanfaatan TIK sebagai media pebelajaran: (a) belum semua ruang pembelajaran dilengkapi komputer dan LCD, (b) ada guru prakarya yang kurang terampil memanfaatkan TIK sebagai media pembelajaran, dan (c) guru belum memanfaatkan e_mail yang dimiliki sebagai media pembelajaran. (3) Solusinya penambahan komputer dan LCD pada ruang pembelajaran, memfasilitasi peningkatan ketrampilan guru dalam pemanfaatan TIK sebagai media pembelajaran, dan menyarankan guru memiliki alamat e_mail dan memanfaatkannya sebagai media pembelajaran.
\end{abstract}

Kata kunci: teknologi informasi dan komunikasi, proses pembelajaran

\begin{abstract}
This research aims to find out how the use of Information and Communication Technology as learning media on craft subject at MTs Negeri 5 Demak, to know what are the problems in using of Information and Communication Technology as media in learning process at MTs Negeri 5 Demak, and to know what is the affort that the done to overcome some problems in using the Information and Communication Technology as media in learning process at MTs Negeri 5 Demak. The result of research show (1) The use of Information and Communication Technology (ICT) as learning mediaon craft subject are maximal enough (2) the problem in using of Information and Communication Technology (ICT) as media in learning process are: (a) there are some classrooms don't have LCD and Computer, (b) there are some craft teacher who can't use Information and Communication Technology well as media in learning process, (c) Teacher doesn't use email yet as media in learning process. (3) The problem solving are the computer and $L C D$ in the classroom will be added, the school must give good facility to increase the creativity in using ICT as media in learning process, make email and use it as media in learning process.
\end{abstract}

Keywords: information and communication technology, learning process

\section{Info Artikel}

Diterima Oktober 2019, disetujui November 2019, diterbitkan Desember 2019 


\section{PENDAHULUAN}

Latar Belakang Masalah, Media Pembelajaran adalah alat bantu yang digunakan untuk memperagakan fakta, konsep, prinsip atau prosedur tertentu agar tampak lebih nyata/konkrit. Alat-alat bantu itu dimaksudkan untuk memberikan pengalaman lebih konkrit, memotivasi serta meningkatkan daya serap dan daya ingat siswa dalam balajar. Media dapat menumbuhkan sikap positip siswa terhadap materi dan proses belajar. Proses pembelajaran menjadi lebih menarik apabila menggunakan media yang tepat sehingga siswa termotifasi untuk mencintai ilmu pengetahuan yang sedang dipelajarinya. Seorang guru dapat efektif dan efisien dalam menyajikankan materi pelajaran apabila dapat memanfaatkan media secara baik dan tepat. Pemanfaatan media dalam pembelajaran akan berdampak efisienasi waktu sehingga guru memiliki cukup waktu untuk memberi perhatian dalam membantu kesulitan belajar siswa, pembentukan kepribadian, dan memotivasi belajar.

Mata pelajaran Prakarya bertujuan untuk mengembangkan pengetahuan, ketrampilan dan sikap percaya diri siswa melalui produk yang dihasilkan sendiri dengan memanfaatkan potensi sumber daya alam yang ada dilingkungan sekitar. Prakarya juga merupakan ilmu terapan yang mengaplikasikan pelbagai bidang ilmu pengetahuan untuk menyelesaikan masalah praktis yang secara langsung mempengaruhi kehidupan kita sehari-hari.

Ruang lingkup mata pelajaran Prakarya untuk tingkat SMP/MTs kelas IX meliputi empat aspek, yaitu Kerajinan, Rekayasa, Budidaya dan pengolahan. Dimana dari keempat aspek tersebut para siswa diharapkan mampu membuat produk dengan memanfaatkan poyensi dari alam sekitar. Untuk membantu siswa dalam memahami materi prakarya pada setiap pembahasan selain disertai gambar dan penugasan, juga memanfaatkan media pemabelajaran yang berbasis TIK yang mampu mengajak siswa untuk aktif bereksplorasi mencari ide-ide baru melalui media internet khususnya dan memanfaatkan media TIK untuk mempresentasikan ide dan proses pembuatan produk prakarya.

Pemanfaatan Teknologi Informasi dan Komunikasi sebagai media pembelajaran prakarya menuntut guru prakarya mampu dan mau menyajikan materi pelajaran dengan menggunakan multimedia dan internet atau berbasis TIK dan siswa dapat memanfaatkan TIK dalam proses pembelajaran.

Teknologi Informasi dan Komunikasi (TIK) adalah sekumpulan perangkat dan sumber daya teknologi yang digunakan untuk berkomunikasi, penciptaan, penyebaran, penyimpanan dan pengolahan informasi atau teknologi yang dapat mereduksi batasan ruang dan waktu untuk mengambil, memindahkan, menganalisa, menyajikan, menyimpan dan menyampaikan informasi data menjadi sebuah informasi. Dalam pendidikan manfaat Teknologi Informasi dan Komunikasi (TIK) dikategorikan menjadi empat yaitu; pertama TIK sebagai gudang ilmu pengetahuan, dimanfaatkan sebagai referensi ilmu pengetahuan terkini, manejemen pengetahuan, jaringan pakar beragam bidang ilmu, jaringan antar instansi pendidikan, pusat pengembangan materi ajar, dan wahana pengembangan kurikulum. Kedua TIK sebagai alat bantu pembelajaran, sekurang-kurangnya ada tiga fungsi TIK yang dapat dimanfaatkan seharihari di dalam proses pembelajaran, yaitu (a) TIK sebagai alat bantu guru yang meliputi animasi peristiwa, alat uji siswa, sumber referensi ajar, evaluasi kinerja siswa, simulasi kasus, alat peraga visual, dan media komunikasi antar guru. (b) TIK sebagai alat bantu interaksi guru- siswa yang meliputi komunikasi guru-siswa, kolaborasi kelompok studi, dan manejemen kelas terpadu. (c) TIK sebagai alat bantu siswa meliputi : buku interaktif, belajar mandiri, latihan soal, media ilustrasi, simulasi pelajaran, alat karya siswa, dan media komunikasi antar siswa. Ketiga TIK sebagai fasilitas pembelajaran, dimanfaatkan sebagai : perpustakaan elektronik, kelas visual, aplikasi multi media, kelas teater multimedia, kelas jarak jauh, papan elektronik dan Keempat TIK sebagai infra struktur. merupakan dukungan teknis dan aplikasi untuk pembelajaran baik dalam skala menengah maupun luas 
Perkembangan teknologi dapat berdampak negatif terhadap siswa apabila dalam pemanfaatannya kurang tepat, pembelajaran berbasis internet menjadi alternatif peralihan dampak negatif internet menjadi dampak positif. Pemanfaatan Teknologi Informasi dan komunikasi (TIK) dalam proses pembelajaran di sekolah sudah merupakan kebutuhan dan keharusan mengingat kemajuan, perkembangan ilmu pengatahuan, dan tuntutan jaman serta menjawab tantangan jaman. Teknologi internet menjadi teknologi tepat guna dengan fasilitas seperti sumber informasi dan data yang dapat diakses secara cepat tanpa batasan jarak, waktu dan tempat. Internet menjadi pusat layanan penting dalam segala bidang termasuk dalam bidang pendidikan. Teknologi komputer dan internet dapat dijadikan sumber belajar dan media pembelajaran.

Pemanfaatan teknologi komputer dan internet dalam pembelajaran khususnya dalam pembelajaran mata pelajaran prakarya belumlah optimal disebabkan fasilitas yang kurang maksimal dan masih relatif banyak guru belum menguasai teknologi komputer dan internet. Belum optimalnya pemanfaatan Internet untuk proses pembelajaran akan berdampak negatif terhadap siswa. Perlunya inovasi pembelajaran yang memanfaatkan internet sehingga pembelajaran dapat diminati oleh siswa tanpa terpaksa. Guru diharapkan dapat menggunakan teknologi internet karena dapat menjadi alternatif dalam mendesain pembelajaran yang lebih menarik, interaktif, dan variatif.

Pembelajaran merupakan suatu rangkaian peristiwa yang kompleks dan sistematis. Suherman (2003) mengungkapkan Pembelajaran pada hakekatnya adalah kegiatan guru dalam membelajarkan siswa. Ini berarti proses pembelajaran adalah membuat atau menjadikan siswa dalam kondisi belajar. Belajar dan mengajar adalah dua kegiatan yang terjadi bersamaan, tetapi memiliki makna yang berbeda, sebagaimana yang diungkapkan Suherman (2003) bahwa "Peristiwa mengajar selalu disertai dengan peristiwa belajar, ada guru yang mengajar maka ada pula siswa yang belajar. Namun, ada siswa yang belajar belum tentu ada guru yang mengajar, sebab belajar bisa dilakukan sendiri." Undang Undang Sistem Pendidikan Nasional (UUSPN) No.20 tahun 2003 mengatakan pembelajaran adalah proses interaksi siswa dengan guru dan sumber belajar pada suatu lingkungan belajar." Dalam artian pembelajaran merupakan proses belajar yang diciptakan guru dengan tujuan untuk mengembangkan kreativitas berfikir siswa sehingga kemampuan berfikir juga meningkat. Menurut Syaiful Sagala, (2003). Pembelajaran mempunyai dua karakteristik yaitu: Pertama, dalam proses pembelajaran melibatkan proses mental siswa secara maksimal, bukan hanya menuntut siswa sekedar mendengar, mencatat akan tetapi menghendaki aktivitas siswa dalam proses berfikir. Kedua, dalam pembelajaran membangun suasana dialogis dan proses tanya jawab terus menerus yang diarahkan untuk memperbaiki dan meningkatkan kemampuan berfikir itu dapat membantu siswa untuk memperoleh pengetahuan yang mereka konstruksi sendiri.

Kreativitas guru prakarya sangat berperan dalam mengembangkan model-model pembelajaran yang disesuaikan dengan kondisi siswa serta sarana dan prasarana yang ada, dalam hal ini guru prakarya harus mampu memanfaatkan teknologi sebagai media pembelajaran. Pembelajaran berbasis TIK adalah a teaching process directly involving a computer in the presentation of instructional material in an interactive mode to provide and control the individualized learning environment for each individual student. (Hick dan Hyde dalam Wena, 2009 )

Inovasi pembelajaran dengan memanfaatkan teknologi komputer dan internet akan memberikan suasana berbeda terhadap persepsi siswa terhadap permbelajaran. Pembelajaran lebih bermakna, pembelajaran dengan memanfaatkan komputer dan internet yang lebih dikenal dengan pembelajaran berbasis web merupakan wujud dari pembelajaran e-learning (electronic Learning). Pembelajaran berbasis web akan mempunyai kelebihan yang dapat memberikan fleksibilitas, interaktifitas, kecepatan dan visualisasi dalam proses pembelajaran. Dengan TIK 
dikembangkan strategi, metode pembelajaran yang menarik, efektif dan efisien, serta melahirkan generasi muda yang menguasai TIK, kreatif dan inovatif. Isjoni (2005) mengemukakan pembelajaran menggunakan internet memiliki sifat interaktif, sebagai media masa dan interpersonal, dan gudang informasi.

Internet merupakan jaringan informasi terluas saat ini. Fadli (2009) mengatakan bahwa internet adalah jaringan komputer yang saling terhubung ke seluruh dunia tanpa mengenal batas teritorial, hukum dan budaya. "Internet adalah jaringan informasi komputer mancanegara yang berkembang sangat pesat dan pada saat ini dapat dikatakan sebagai jaringan informasi terbesar di dunia, sehingga sudah seharusnya para profesional mengenal manfaat apa yang dapat diperoleh melalui jaringan ini." (Sanjaya, 1995).

Internet memberikan kesempatan untuk mendapatkan informasi secara cepat dan tidak terbatas. Perkembangan teknologi internet akan berdampak pada semua bidang termasuk bidang pendidikan. Lebih lanjut, Udin Saefudin Su'ud (2008) menjelaskan internet mempunyai karakteristik sehingga bisa digunakan sebagi media pembelajaran. Karakteristiknya antara lain: (1) media interpersonal dan media massa yang memungkinkan terjadinya komunikasi one-toone maupun one-to-many, (2) bersifat interaktif, (3) memungkinkan terjadinya komunikasi secara sinkron maupun tertunda, sehingga terselenggaranya ketiga jenis komunikasi yang merupakan syarat sebuah pembelajaran.

Disisi lain, Kemp \& Dayton (dalam Fadli, 2009) menyatakan bahwa media pembelajaran mempunyai manfaat, antara lain: (1) Penyampaian pembelajaran menjadi lebih baku. Setiap siswa yang melihat atau mendengar penyajian melalui media menerima pesan yang sama, (2) Pengajaran bisa lebih menarik, (3) Pembelajaran menjadi lebih interaktif, (4) Lama waktu pembelajaran yang diperlukan dapat dipersingkat, (5) Kualitas hasil belajar dapat ditingkatkan, (6) Sikap positif siswa terhadap apa yang mereka pelajari dan terhadap proses belajar dapat ditingkatkan. Lebih lanjut, Nasution (2005) menjelaskan bahwa manfaat media CAI (Computer Assisted Instruction) yang selanjutnya berkembang menjadi web sebagai media pembelajaran adalah: membantu siswa dan guru dalam pembelajaran yang sangat cocok untuk latihan dan remedial teaching, memberikan informasi secara lengkap dan cepat, fleksibel dalam pembelajaran dan dapat diatur sesuai yang diharapkan, dan dapat menampilkan penilaian secara cepat. Ada 3 bentuk sistem pembelajaran melaui internet, seperti yang dijelaskan Nurhakim (2007), diantaranya:

Web Courses, ialah penggunaan internet untuk pembelajaran, dimana seluruh bahan ajar, diskusi, konsultasi, penugasan, latihan dan ujian sepenuhnya dilakukan melalui internet. Peserta didik dan pengajar sepenuhnya terpisah, namun hubungan atau komunikasi antara peserta didik dan pengajar dapat dilakukan setiap saat.

Web Centric Courses, dimana sebagian bahan ajar, diskusi, konsultasi, penugasan, latihan dilakukan melalui internet, sedangkan ujian dan sebagian konsultasi, diskusi dan latihan dilakukan secara tatap muka.

Web Enhanced Courses, yaitu pemanfaan internet dalam pendidikan untuk menunjang kualitas kegiatan belajar mengajar di kelas. Pada bentuk ini persentase pembelajaran melalui internet lebih sedikit dibandingkan kegiatan tatap muka, karena penggunaan internet hanya untuk mendukung kegiatan pembelajaran secara tatap muka.

Sistem Pembelajaran prakarya di MTs Negeri 5 Demak tempat penelitian menggunakan sistem pembelajaran Web Enhanced Courses, yaitu pembelajaran yang memanfaatkan Teknologi Informasi dan Komunikasi sebagai pendukung pembelajaran yang dilakukan secara tatap muka. Isjoni (2005) menjelaskan pada pengembangan web enhanced course internet berfungsi untuk memberikan pengayaan dan media komunikasi peserta didik dengan pengajar, sesama peserta didik. Namun, komunikasi timbal balik antara peserta didik dan pengajar dapat juga dilakukan pada saat pembelajaran berlangsung, mengingat peserta didik masih pemula. 
Penyampaian materi, diskusi, latihan dan penugasan dilakukan menggunakan internet, tetapi guru dapat memberikan penjelasan langsung jika siswa menghadapi permasalahan.

Fungsi pembelajaran elektronik, ada tiga fungsi pembelajaran elektronik dalam kegiatan pembelajaran di kelas yaitu sebagai suplemen yang sifatnya pilihan/opsional, sebagai pelengkap (komplemen), atau sebagai pengganti (substitusi). (Siahaan dalam Puranti, 2002). Pembelajaran dengan media elektronik yang berfungsi sebagai suplemen (tambahan), peserta didik mempunyai kebebasan memilih, apakah akan memanfaatkan materi pembelajaran elektronik atau tidak. Meskipun sifatnya pilihan, peserta didik yang memanfaatkannya tentu akan memiliki tambahan pengetahuan atau wawasan.

Pembelajaran dengan media elektronik yang berfungsi sebagai komplemen (pelengkap), materi pembelajaran elektronik diprogramkan untuk melengkapi materi pembelajaran yang diterima siswa di kelas. Sebagai komplemen berarti materi pembelajaran elektronik diprogramkan untuk menjadi materi reinforcement (pengayaan) atau remedial bagi siswa dalam mengikuti kegiatan pembelajaran konvensional. Dikatakan berfungsi sebagai pengganti bertujuan sebagai alternatif model kegiatan pembelajaran kepada siswa. Tujuannya agar para siswa dapat secara fleksibel mengelola kegiatan pembelajarannya sesuai dengan waktu dan aktivitas lain sehari-hari. Terkait dengan fungsi pembelajaran elektronik tersebut, ada tiga alternatif model kegiatan pembelajaran yang dapat dipilih siswa, yaitu: (1) sepenuhnya secara tatap muka (konvensional), (2) sebagian secara tatap muka dan sebagian lagi melalui internet, atau bahkan (3) sepenuhnya melalui internet.

\section{METODE PENELITIAN}

Penelitian ini menggunakan pendekatan kualitatif, karena penelitian ini berusaha untuk mendiskripsikan pemanfaatan Teknologi Informasi dan Komunikasi sebagai media pembelajaran pada mata pelajaran prakarya, mengetahui kendala-kendala yang dihadapi dalam pemanfaatan Teknologi Informasi dan Komunikasi sebagai media pembelajaran serta mengetahui solusi-solusi yang diambil dalam menghadapi kendala tersebut.

Metode kualitatif secara khusus menghasilkan kekayaan data yang rinci tentang banyak orang dan banyak kasus (Patton,2006). Penelitian kualitatif bersifat induktif yaitu pengembangan konsep yang didasarkan atas data yang ada, mengikuti desain penelitian yang fleksibel sesuai konteksnya. Metode penelitian kualitatif adalah metode penelitian yang dipakai pada kondisi obyek yang alamiah (Sugiyono,2006).

Penelitian ini dilakukan di MTs Negeri 5 Demak kabupaten Demak, hal ini peneliti pilih dikarenakan MTs Negeri 5 Demak adalah sekolah yang menurut peneliti mempunyai peralatan (fasilitas ) Teknologi Informasi dan Komunikasinya lebih lengkap dibanding dengan sekolahsekolah yang ada disekitarnya. Teknologi Informasi dan Komunikasi (TIK) adalah berbagai bentuk peralatan dan system yang digunakan untuk memperoleh, memproses, mengelola, memanipulasi, memindah, menyimpan dan menyebarkan informasi melalui media elektronik (Isjoni et al., 2008 ).

Untuk memperoleh data peneliti melukukan studi dokumen dan pengamatan lapangan, serta melakukan wawancara dengan berbagai informan. Informan dalam penelitian ini adalah Kepala sekolah, Urusan Hubungan Masyarakat, Urusan Kurikulum, Guru dan Siswa serta angota Komite Sekolah yang berada di MTs Negeri 5 Demak. 


\section{HASIL PENELITIAN DAN PEMBAHASAN}

Berdasarkan data yang diperoleh dan dianalisis, dapat dipaparkan hasil penelitian yang sebagai berikut:

1. Pemanfaatan Teknologi Informasi dan Komunikasi (TIK) sebagai media pembelajran di MTs Negeri 5 Demak adalah cukup maksimal. Hal ini ditandai dengan frekuensi pemanfaatan dan optimalisasi pemanfaatan fasilitas TIK sebagai media pembelajaran yang peneliti rangkum seperti pada tabel 1 dibawah ini

\section{Tabel 1}

Pemanfaatan TIK sebagai media pembelajaran

\begin{tabular}{|c|c|c|c|}
\hline Jenis Fasilitas & Tujuan Pemanfaatan & $\begin{array}{c}\text { Frekuensi } \\
\text { pemanfaatan }\end{array}$ & $\begin{array}{l}\text { Optimalisasi } \\
\text { Pemanfaatan }\end{array}$ \\
\hline Komputer & $\begin{array}{c}\text { Efektifitas dan efisiensi } \\
\text { Pembelajaran }\end{array}$ & besar & Cukup maksimal \\
\hline LCD Proyektor & Fariasi pembelajaran & besar & Cukup Maksimal \\
\hline e_mail & $\begin{array}{l}\text { Pembelajaran tidak kenal } \\
\text { batasan waktu dan tempat }\end{array}$ & $\begin{array}{c}\text { Baru sebatas } \\
\text { mengenal e-mail }\end{array}$ & Tidak maksimal \\
\hline WEB & $\begin{array}{c}\text { Pembelajaran tidak kenal } \\
\text { batasan waktu dan tempat serta } \\
\text { informasi dapat diperoleh dari } \\
\text { mana saja }\end{array}$ & $\begin{array}{l}\text { informasi sekolah } \\
\text { secara umum }\end{array}$ & Cukup Maksimal \\
\hline
\end{tabular}

Berdasaran tabel tersebut dapat dikemukakan bahwa pemanfaatan komputer, LVCD profektor relatif baik, terlihat dari frekuensi pemanfaatan dan optimalisasi pemanfatannya, demikian juga berkenaan dengan WEB. Namun penggunaan email belum dimanfaatkan secara maksimal dan frekuensi pemanfaatan terbatas pada tarah pengenalan.

2. Kendala Pemanfaatan TIK sebagai Media Pembelajaran

a. Terbatasnya komputer dan LCD sebagai media pembelajaran (Komputer dan LCD belum tersedia di setiap ruang pembelajaran)

b. Masih ada guru dalam mengoperasikan komputer dan LCD kurang terampil.

c. guru banyak yang tidak memiliki alamat E_mail, temuan ini didukung dengan tidak lengkapnya arsip tentang alamat E_mail pribadi guru .

d. guru belum banyak yang menulis pada WEB sekolah, peneliti peroleh data bahwa pada WEB Sekolah yang menulis masih guru tertentu atau masih sebatas informasi umum artinya WEB belum dimanfaatkan sebagai media pembelajaran

Kendala pemanfaatan E_mail dan WEB sebagai media pembelajaran adalah guru belum terbiasa atau kurang terampil menulis pada WEB dan guru belum terbiasa memanfaatkan E_mail yang dimiliki. 
3. Solusi dalam mengatasi kendala pemanfaatan TIK sebagai media pembelajaran di MTs Negeri 5 Demak berdasar penelitian dapat peneliti rangkum seperti tabel berikut

Tabel 4.

Ringkasan Solusi

\begin{tabular}{|c|c|c|}
\hline Masalah & Kendala & Solusi \\
\hline $\begin{array}{l}\text { Pemanfaatan komputer } \\
\text { sebagai media pmbelajaran }\end{array}$ & $\begin{array}{l}\text { - Satu ruang pembelajaran } \\
\text { hanya ada satu computer } \\
\text { - Guru kurang terampil } \\
\text { menyusun perangkat } \\
\text { pembelajaran berbsis TIK }\end{array}$ & $\begin{array}{l}\text { - Mengajukan blockgrand ke } \\
\text { Pemerintah dan anggota } \\
\text { komite sekolah } \\
\text { - Mengadakan diklat atau } \\
\text { mengikutsertakan diklat } \\
\text { pada lembaga lain }\end{array}$ \\
\hline $\begin{array}{l}\text { Pemanfaatan LCD } \\
\text { proyektor sebagai media } \\
\text { pembelajaran }\end{array}$ & $\begin{array}{l}\text { - Kurang lancar } \\
\text { mengoperasikan LCD }\end{array}$ & $\begin{array}{l}\text { - Mengadakan diklat } \\
\text { peningkatan ketrampilan } \\
\text { mengoperasikan LCD }\end{array}$ \\
\hline $\begin{array}{l}\text { Pemanfaatan E_mail } \\
\text { sebagai media pmbelajaran }\end{array}$ & $\begin{array}{ll}\text { - Kurang memanfaatkan } \\
\text { E_mail }\end{array}$ & $\begin{array}{l}\text { - Menganjurkan } \\
\text { memanfaatkan Email }\end{array}$ \\
\hline $\begin{array}{l}\text { Pemanfaatan WEB sebagai } \\
\text { media pembelajaran }\end{array}$ & $\begin{array}{l}\text { - Kurang terbiasa menulis } \\
\text { pada WEB }\end{array}$ & $\begin{array}{cc}\text { - Menyarankan } & \text { atau } \\
\text { mengadakan } & \text { pelatihan } \\
\text { tentang WEB } & \end{array}$ \\
\hline
\end{tabular}

Hasil wawancara dengan beberapa informan dan pengamatan lapangan serta studi dokumen di MTs Negeri 5 Demak dapat disimpulkan:

1. Pemanfaatan Teknologi Informasi dan Komunkasi (TIK) sebagai media pembelajaran cukup maksimal,

2. Kendalanya: belum semua ruang pembelajaran dilengkapi dengan perangkat komputer dan LCD, adanya guru yang kurang terampil memanfaatkan TIK sebagai media pembelajaran dan belum terbiasa menulis pada WEB sekolah, serta belum memanfaatkan email yang dimiliki sebagi media pembelajaran

3. Solusinya: berusaha melengkapi setiap rung pembelajaran dengan perangkat komputer dan LCD, memfasilitasi guru-guru untuk meningkatkan ketrampilan dalam memanfaatkan Teknologi Informasi dan Komunkasi (TIK) sebagai media pembelajaran,memfasilitasi guru untuk menulis pada web sekolah dan Menyarankan emiliki alamat E_mail pribadi serta memanfaatkannya sebagai sarana media pembelajaran. 


\section{DAFTAR PUSTAKA}

Depdiknas, (2009). Panduan Pelaksanaan Pembinaan SMP RSBI, Direktorat Pembinaan Sekolah Menengah Pertama Direktorat Jendral Manajemen Pendidikan Dasar dan Menengah,Jakarta

Nasution. (2005). Teknologi Pendidikan. Jakarta, Bumi Aksara

Patton, (2006). Metode Evaluasi Kualitatif(How to Use Qualitative Methodes in Evaluation). Pustaka Pelajar. Yogyakarta

Peraturan Pemerintah no.19 tahun 2005 tentang Standar Nasional Pendidikan Sa'ud, Udin Saefudin. (2008). Inovasi Pendidikan . Bandung: Alfabeta Sagala.(2005).Administrasi Pendidikan Kontemporer. Bandung: Alfabeta

Suherman dkk,2003.Strategi Pembelajaran Kontemporer,UPI.Bandung Undang-Undang no.20 tahun 2003 tentang sistem pendidikan Nasional 